\title{
Clastic Quaternary Sediments of the
} Augšdaugava Spillway Valley as Natural
Resources - Grain Size Distribution and Micromorphology of Quartz Grains as Indicators for Distinguishing Alluvial and Glaciofluvial Sand Deposits

\author{
Juris Soms \\ Daugavpils University \\ Daugavpils, Latvia \\ juris.soms@du.lv
}

\author{
Ēriks OŠMJANSKIS \\ Daugavpils University \\ Daugavpils, Latvia \\ eriks.osmjanskis@gmail.com
}

\begin{abstract}
Alluvial and glaciofluvial sand and gravel deposits are the significant natural resources of the Augšdaugava spillway valley. Considering that these sediments differ in granulometric composition and degree of sorting, which in turn determine their utilisation, it is substantially to distinguish sediments of different origin. Hence the main objective of this study was to assess grain size distribution and micromorphology of quartz grains as indicators for distinguishing alluvial and glaciofluvial sands. The grain size distribution has been identified by the laser diffraction method, but the micromorphology of quartz grains has been analysed by scanning electron microscopy. The obtained data indicate that results of the granulometric composition analysis can be used for the discrimination of alluvial and glaciofluvial sediments, in contrast, micromorphology cannot be a reliable diagnostic indicator for identifying the sand of different origin.
\end{abstract}

Keywords - alluvial sediments, glaciofluvial sediments, grain size distribution, micromorphological analysis.

\section{INTRODUCTION}

Clastic Quaternary sediments of the Augšdaugava spillway valley, particularly alluvial and glaciofluvial sand and gravel deposits are both the important constituents of the geological structure of the spillway terraces and significant natural resources which can be utilised for economic needs [1]. However, considering that for different sectors of application it is a necessity for non-sorted, or, to the contrary, sorted material [2], it is need for identification, distinguishing and subsequent mapping of sand sediments of different origin. This is important because alluvial and glaciofluvial sediments differ in granulometric composition [3], [4], therefore using of inappropriate material increases the costs due to additional processing, e.g. sieving [5].

Vertical sequence composed of flowing-water material deposits making up terraces in the Augšdaugava spillway valley include sediments deposited by glacial meltwater streams and alluvium left by the river. Distinguishing these deposits from each other and from other similar clastic sediments, e.g., aeolian sands is an essential task in geological survey and mapping of mineral resources. Review of scientific literature reveal that significant efforts have been made on deciphering Quaternary records and elucidation of indicators suitable for discrimination of depositional environments using different sedimentary characteristics [6]-[8]. However, the conventional field studies and examination of sand samples in situ do not allow straightforward and definite distinguishing of glaciofluvial sediments from the alluvial ones. At the same time searches for the ex situ methodology and indicators appropriate for solving of this task is still under development [9].

Hence the main goal of the study presented in this article was to assess grain size distribution and micromorphology of quartz grains as indicators for distinguishing alluvial and glaciofluvial sands. The specific objectives of the study discussed herein were (1) to carry out geological field survey and to collect sand samples from different locations in the Augšdaugava spillway valley for subsequent examination at laboratory; (2) to perform granulometric and micromorphological analysis of collected sand samples; (3) to process the acquired data for obtaining grain-size statistical parameters and their graphic representations; (4) to compare applied research methods and to evaluate the reliability of related diagnostic indicators for identifying the sand of different origin.

\section{Materials AND METHODS}

The sand samples were collected in different locations of the Augšdaugava spillway valley in the course of the geological field surveys in 2017 and 2018. The natural outcrops of clastic Quaternary sediments and sand-gravel quarries, as well as fluvial landforms like river point bars and mid-channel bars were selected as sampling sites, and their precise location have been georeferenced by GPS.

Print ISSN 1691-5402

Online ISSN 2256-070X

http://dx.doi.org/10.17770/etr2019vol1.4094

(C) 2019Juris Soms, Eriks Ošmjanskis.

Published by Rezekne Academy of Technologies.

This is an open access article under the Creative Commons Attribution 4.0 International License. 
The shallow check pits had been excavated, only sections of similar lithofacies and with comparable granulometric sediment composition had been chosen for sand sampling. Following the standard procedure described by Evans and Benn [10], one or more representative bulk samples each with a mass of about $200 \mathrm{~g}$ were taken from the manually cleaned sections at a depth of 0.6 to $1.2 \mathrm{~m}$ and stored in labelled plastic bags. In a total of 51 bulk sand samples for further analysis were collected.

All of the samples were oven-dried at $60^{\circ} \mathrm{C}$. Before the grain-size analysis organic matter was removed following the procedure described by Konert and Vandenberg [11], treating the samples with $30 \%$ hydrogen peroxide $\mathrm{H}_{2} \mathrm{O}_{2}$. Pre-treated samples were soaked in a sodium hexametaphosphate $\left(\mathrm{NaPO}_{3}\right)_{6}$ solution $\left(5 \mathrm{~g} \mathrm{~L}^{-1}\right)$ to break cohesion and then were analyzed with a Mastersizer 2000 equipped with Hydro 200MU dispersion unit in the Laboratory of Quaternary Environment, Daugavpils University. The measurement range of this laser diffraction particle size analyzer is $0.02-2000 \mu \mathrm{m}$.

Pre-treated sand samples were gradually suspended in deionised water until optimal obscuration range between $10 \%$ and $20 \%$ was reached. Then, the suspension was subjected to $60 \mathrm{~s}$ ultrasonification at stirrer speed 3200 rpm to achieve homogenous dispersion. The Mie theory was applied for calculating the particle size [12], using a refractive index of 1.333 for deionised water and 1.55 for the particles. The duration of each measurement was $30 \mathrm{~s}$. Considering that possible abnormal values obtained during particle size analysis may affect the reliability of the data, each sample was measured six times to recognize and reject outliers by using of Q-criterion and hence to produce the relevant averaged result. The estimated error of replicate measurements was within $0.3 \%$.

Subsequently obtained records on grain size composition were exported as Excel data tables. It allowed the calculations of the granulometric indicators according to the formulas reported by Folk and Ward [13], i.e., the mean grain size $\left(M_{z}\right)$, the sorting coefficient $(\sigma)$, and the skewness $\left(S_{k}\right)$ of each sample. For this purposes, GRADISTAT module was applied [14]. The phi unit ( $\Phi)$ as a logarithmic transformation of grain size metric values into whole integers was used, according to the formula: $\Phi=-\log _{2} d$, where $d=$ grain diameter in $\mathrm{mm}$. For graphic representations data of granulometric analysis of each sample were plotted as particle size distribution frequency diagrams.

The micromorphology of quartz grains, i.e. analysis of roundness, relief and surface microtextures has been performed by scanning electron microscopy (SEM). Considering the high costs of SEM method, only 12 samples were selected for analysis from a total of 51 sand samples collected. At first, sand fraction samples with a particle size range of 250 to $500 \mu \mathrm{m}$, or from 1 to $2 \Phi$ values, were obtained by the wet sieve method. Prior to obtaining micrographs of quartz grain by SEM, chemical pre-treatment of samples by citrate-bicarbonateditionate method has been performed to clean carbonates and iron oxide coatings from the grain surfaces [15]. Using an optical microscope, 25 quartz grains were taken randomly in each of the 10 samples and put on the carbon double sticky tape on top of the SEM specimen holder. The quartz grain specimens were examined by SEM Phenom ProX at $15 \mathrm{kV}$ voltage and $400 \times$ magnification.
For studies of details on the surface of quartz grains and identification of microtextures, higher magnifications up to $2500 \mathrm{x}$ were used. In total, 300 micrographs of alluvial and glaciofluvial sand quartz grains were obtained with a SEM. Later micromorphological analysis was performed according to the methodology described in the literature [16], [17].

\section{RESUlTS AND DISCUSSION}

The analysis of grain size of clastic Quaternary sediments is usually applied to study the transportation and deposition processes, sedimentary environments, and provenance and sources of deposited material [18]. It also can also be used to infer the direct information on the applicability of these natural resources as raw material for using in different sectors of the economy depending on the degree of sorting, e.g. producing of concrete building elements or masonry mortars or fillers, where non-sorted material, or, to the contrary, sorted material is needed, respectively. Thus, the analysis of granulometric parameters of the sediments is the basis for both the obtaining scientific data on transportation mechanisms and the environments and ascertaining the material quality in terms of practical usefulness in the specific sectors. In order to elucidate the possibility to distinguish practically the alluvial sand from the glaciofluvial sand on the basis of granulometric composition, frequency diagrams as graphic representations of grain size distribution were analysed and compared. To illustrate the difference, some samples with grain size distribution characteristics typical for alluvial and glaciofluvial sand are shown below. Common regularity is that alluvial sandy deposits have a predominantly unimodal grain size distribution (Fig. 1A and 1B) with modes typically between 300 and $530 \mu \mathrm{m}$.
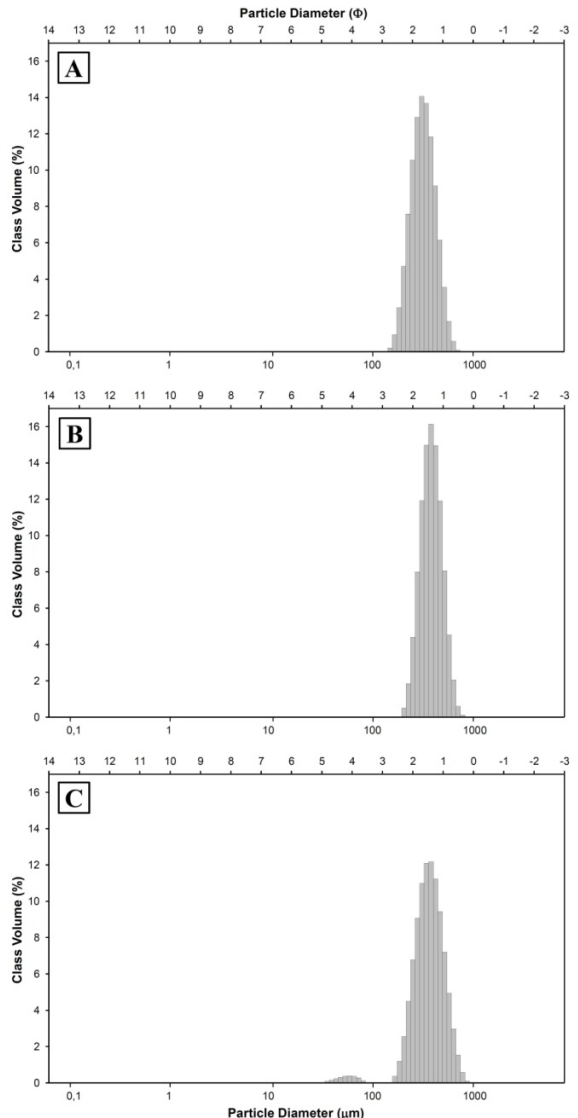

Fig. 1. Examples of grain size distribution of alluvial sediments. Most of the alluvial sand samples have the typical symmetric bellshaped grain size distribution pattern (A and B), and some samples with asymmetric pattern indicate a presence of finer fractions (C). 
Considering that the grain size distribution frequency can be expressed as a unimodal distribution diagram, it indicates that the sample is composed of the singlecomponent deposited sediments. Only some alluvial samples indicate the bimodal distribution (Fig. 1C) associated with the presence of fine silt sediments in the sample. This fact can be explained by the sedimentation environment, determined by a fluvial deposition in relatively slow and steady Daugava river flow. The fining of sediments (bimodal distribution) could be related to gradual decreasing of stream velocity due to changes in discharge, or, to the presence of obstacles, e.g. boulders in the river channel, where sedimentation took place at their leeward side due to slower flow and microturbulence.
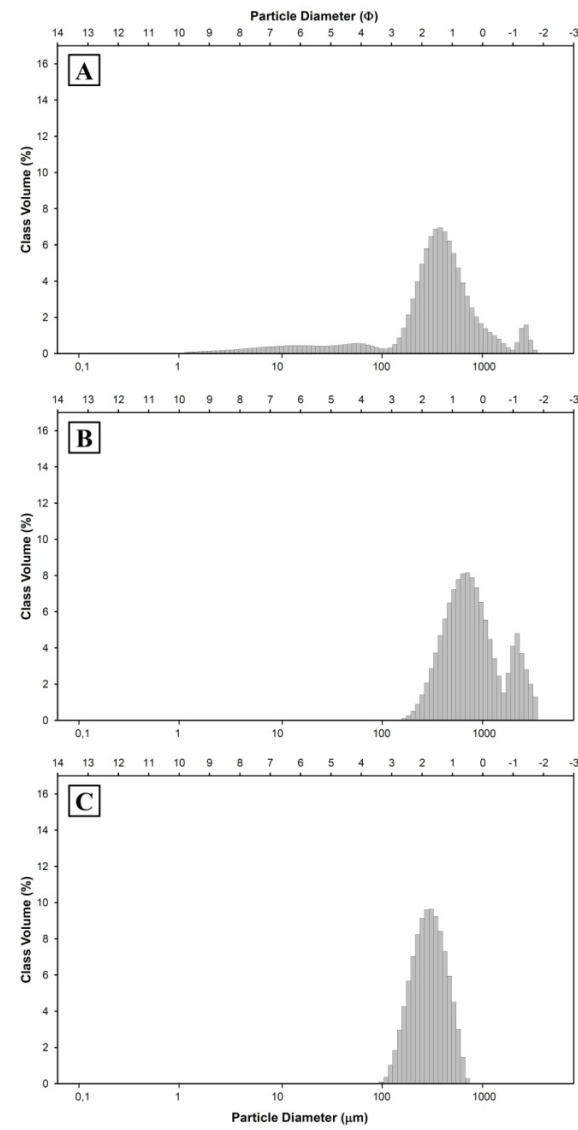

Fig. 2. Examples of grain size distribution of glaciofluvial sediments. Most of the glaciofluvial sand samples have bi- or polymodal asymmetric grain size distribution patterns (A and $B$ ), and some samples with symmetric pattern indicate a presence of wellsorted material $(\mathrm{C})$.

In contrary, for glaciofluvial sandy deposits regularity is that they have a predominantly bimodal or polymodal grain size distribution related to the presence of coarser and finer fractions (Fig. 2A and 2B). Only some glaciofluvial samples indicate the unimodal distribution (Fig. 2C). Information given in scientific literature [18] reveals that if the distribution function of a particle size is polymodal, the sample is composed by the summing up and overlapping of several unimodal functions. In other words, the grain size distribution in a sample is composed of multiple fractions of clastic sediments. Hence glaciofluvial sediments tend to a bi- or polymodal grain size distribution, which in turn can be attributed to mixing of clasts of different fractions by high-energy and turbulent glacial meltwater streams.
In addition to grain size distribution analysis, the relationship and variation trends between such grain-size parameters as mean grain size $(M z)$ and sorting coefficient $(\sigma)$ also was analysed. These data are clues to the deposition mechanisms and can provide insight into the sedimentation environments [19]. The sampled glaciofluvial sands range widely in their mean grain size from sandy fine gravel to fine sand (Wentworth scale) and are positively skewed or near symmetrical with skewness values -0.1 $<S_{k}<+0.30$, whilst alluvial sands range more narrowly from coarse sand to fine sand (Fig. 3) and are symmetrical with skewness values $-0.02<S_{k}<+0.03$. The majority of glaciofluvial sand samples are poorly to moderately sorted $(\sigma$ values $>0.7)$, with well-sorted sediments being exceptional. In contrary, the alluvial sand samples mainly are well to moderately-well sorted with sorting coefficient values $0.35<\sigma<0.5$ (Fig. 3). In general, sorting values confirm the prevalence of water stream transportation and deposition mechanisms. However, there is no clear tend for $\sigma$ values of both alluvial and glaciofluvial sediments to decrease as $M_{z}$ values increases, hence regularity that sorting improves as mean particle size decreases had not been observed. Furthermore, significant overlapping of $M_{z}$ and $\sigma$ value distribution areas in the graph indicates (Fig. 3), that examination of the relationship between the mean grain size and sorting coefficient apart of other methods cannot be used as a straightforward tool for identification of sand origin; only combination of several techniques provides reliable data.

Considering the aforementioned regularities, it is apparent, that analysis of grain size distribution and statistical parameters is applicable for the discrimination of alluvial and glaciofluvial sediments. Therefore, it is proposed that the difference in granulometric composition of the sand samples could be used as the basis for identification and classifying Quaternary deposits for purposes of the extraction of natural resources.

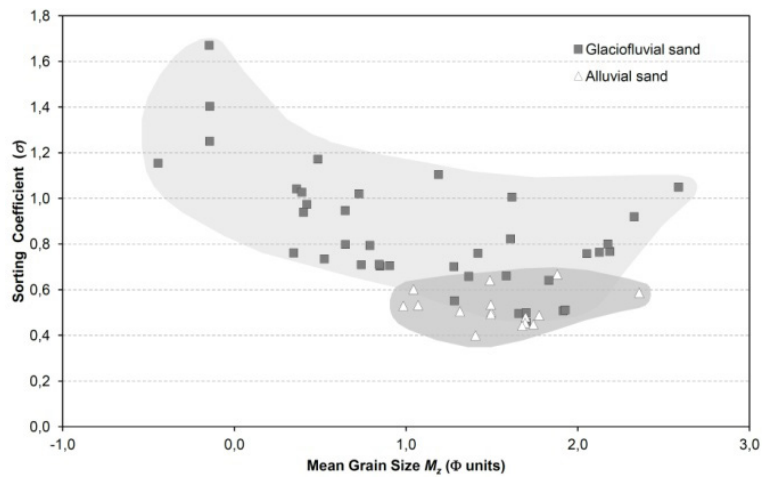

Fig. 3. Relationships between mean grain size and sorting for alluvial and glaciofluvial sands.

The micromorphological examination of quartz grains, including evaluation of their roundness, relief and analysis of surface microtextures by SEM has also been proven as tool for identification of the sedimentary environments, as well as the mechanisms of transportation and deposition of clastic sediments [17], [20]. Data given in the scientific literature indicate that on the basis of SEM analysis of microtextures observed on the quartz grain surfaces, it is possible to identify sands of aeolian origins 
from other environmental distinctions [17]. Quartz grains transported in subaqueous environments are usually more rounded, with lower relief and bearing microtextural signs of impacts like V-shaped percussion marks or triangular etch pits. Considering that discharges and velocities of glaciofluvial streams can be some magnitudes higher than fluvial ones, the high-speed flowing glacial meltwater produces more intense and more frequent high-energetic collisions between sand particles than a river, resulting in cracking of grains and formation of specific microtextures. Hence SEM micromorphological analysis of quartz grains was tested as a method for distinguishing alluvial and glaciofluvial sand deposits.

First of all, rounding degree of quartz grains was estimated from SEM micrographs, distinguishing four roundness classes according to Krrížek et. al. [21], i.e. angular, sub-angular, sub-rounded and rounded grains (Fig. 4). It was assumed that the higher proportion of angular or sub-angular quartz grains in sand sample could indicate the subaqueous, high-energy fluvial environment related to glaciofluvial type of material transportation. Studies performed by other scientists state that angularity is caused by grain crushing without edge rounding in highenergetic subaqueous environments with limited transport distances [21]. The results show that the proportion of angular or sub-angular quartz grains in samples varies widely from $32 \%$ to $12 \%$, however, there is no wellexpressed difference between alluvial and glaciofluvial sands.
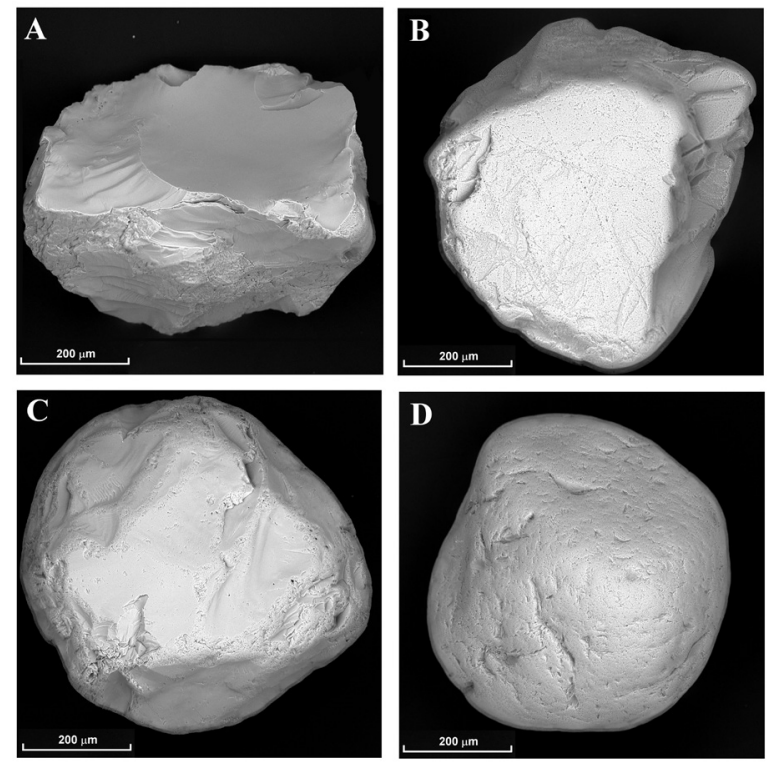

Fig. 4. Representative examples of roundness classes of studied quartz grains: angular (A), sub-angular (B), sub-rounded (C) and rounded (D)

Secondly, the following microtextures were identified on the surface of quartz grains: conchoidal fractures and V-shaped percussion marks (Fig. 5). These features are common for glaciofluvial sediments.

Conchoidal fractures (Fig. 5A) are the slightly curved microcavities with typical, shell-like breakage pattern, which are produced by a powerful impact of other hard mineral aggregates [17]. in high-energy glaciofluvial environments, where collisions between clast particles occur frequently due to high concentrations of poorly sorted sediments, formation of larger conchoidal fractures are common [21].

V-shaped percussion marks (Fig. 5B) are more or less triangular shaped depressions, with dimensions from several $\mu \mathrm{m}$ to some tens of $\mu \mathrm{m}$. Mahaney and Kalm state that $\mathrm{V}$-shaped percussion marks are formed mainly by impacts in fast-flowing, high energetic subaqueous environments with considerable grain-to-grain contact, such as in the glaciofluvial deposits [22].

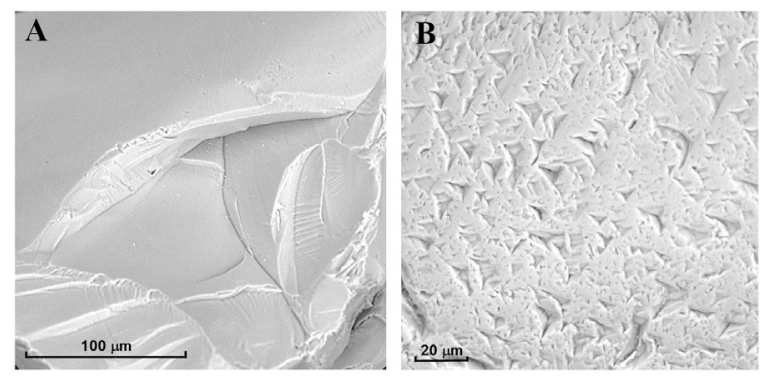

Fig. 5. Studied microtextures as indicators of high-energy glaciofluvial environment: conchoidal fractures (A) and V-shaped percussion marks (B).

Their presence of both types of microtextures was expressed according to Vos et. al. [17] "abundant", when the feature is present on $75 \%$ of the grains, "common" 50-75\%, "sparse" 5-50\%, and "rare" 5\%. Considering that, it was expected to find in the glaciofluvial samples the high proportion of quartz grains characterised by abundantly occurring conchoidal fractures. The results of microtextures analysis reveal that both for alluvial and glaciofluvial samples this indicator in average varies from $8 \%$ to $25 \%$ (maximum $50 \%$ ) without distinct prevalence in glaciofluvial sand. Hence, despite the expected, the examination of this type of microtextures did not allow to find the distinctions between alluvial and glaciofluvial sands. The similar negative result was obtained in the course of analysis of V-shaped percussion marks. These features occur less than $25 \%$ of grains of both sediment types, and, similarly to previous, there is no significant difference between alluvial and glaciofluvial samples, thus making impossible the definite discrimination of samples of different origin on the basis of analysis of V-shaped microtextures.

These findings can be explained by the fact of the geological evolution of the Augšdaugava spillway valley - widening of the valley occurs as a result or river lateral erosion, causing the detachment, entrainment and transport of glaciofluvial sediments making up terraces. During these processes, glaciofluvial sands were reworked and redeposited, and alluvial sediments were enriched by clast grains of glaciofluvial origin. Such a reworked and redeposited alluvial material in the valley can be difficult to identify on the basis of the micromorphological analysis, because the sand grains in this material still retain the indicators of the initial sedimentation environment.

\section{Conclusions}

The data obtained in the result of granulometric studies of alluvial and glaciofluvial sand samples indicate 
that plots of grain size distribution can be used for the discrimination of alluvial and glaciofluvial sediments. The alluvial sediments show mainly unimodal grain size distribution determined by fluvial deposition in a relatively slow and steady flow, whilst glaciofluvial sediments tend to a bi- or polymodal grain size distribution which can be attributed to mixing of clasts of different fractions by turbulent, fast-flowing glacial meltwater streams. This suggests that grain size distribution at the local scale of the Augšdaugava spillway valley is mainly governed by patterns associated with sediment sources and hydraulic sorting.

If the lithofacies or sand sedimentary structures are similar, or other characteristics are indistinct thus hindering in situ recognition of different genetic types of sandy sediments as natural resources, granulometric analysis can be very useful for distinguishing clastic Quaternary sediments. In this case the grain size distribution of alluvial sand can be described as a unimodal distribution diagram, hence indicating single-component deposited sediments. In contrary, glaciofluvial sand can be described as a bi- or polymodal distribution diagram, indicating multiple-component deposited sediments.

Evaluation of SEM as a method for distinguishing alluvial from glaciofluvial material reveal, that despite the expected, results of the micromorphological analysis indicate that neither microtextures, nor roundness or relief of quartz sand grains differ significantly for both types of Quaternary sediments. Therefore, in the case of the 300 specimens of quartz grains from 12 sand samples studied by SEM it is practically impossible to distinguish the alluvial sediments from the glaciofluvial sediments on the basis of their micromorphology. In fact, based on the different kinds of microtextures observed on the quartz grain surfaces, it is impossible to identify alluvial sands from a glaciofluvial origin. Although there are a number of scientific studies concerning the discrimination between water- and wind-transported sediments, the capabilities of scanning electron microscopy to provide an analytical distinction between two groups of similar sediments deposited in the subaqueous environment are not yet enough. In this context, the question arises of whether the micromorphology of quartz grains can be reliable both in discrimination of sediments and as a diagnostic indicator for identifying the natural resources.

In addition, it should be noted, that the data complex obtained in the result of multiproxy studies of alluvial and glacioaquatic sediments indicates significant changes in transport history and depositional conditions during the development of the Augšdaugava spillway valley. Hence further studies of these issues have to be performed.

\section{REFERENCES}

[1] V. Juškevičs, J. Misāns, A. Mūrnieks and J. Skrebels, "Quaternary deposits," in Geological Map of Latvia. Scale 1:200,000. Sheet 34-Jēkabpils. Sheet 24-Daugavpils. Explanatory Text and Maps (Kvartāra nogulumi, Latvijas ǵeolog̣iskā karte mērogā $1: 200000$ 34.lapa - Jēkabpils un 24.lapa - Daugavpils), O. Āboltiņš and A.J. Brangulis, Eds. Rīga: State Geological Survey, 2003, pp. 9-26. (in Latvian).
[2] B. Belhadj, M. Bederina, K. Benguettache and M. Queneudec, "Effect of the type of sand on the fracture and mechanical properties of sand concrete," Advances in Concrete Construction, vol.2 (1), pp. 13-27, 2014.

[3] R.W. Young, "Alluvium," in Encyclopedia of Geomorphology, A.S. Goudie, Ed. London: Routledge, 2004, pp. 19-21.

[4] T. A. Brennand, "Glacifluvial sediment," in Encyclopedia of Geomorphology, A.S. Goudie, Ed. London: Routledge, 2004, pp. 462463.

[5] M. Martišius and H. Sivilevičius, "Estimated Economics of Operation Mobile Screens in Dry Screening Process Production of Final Aggregates for Hot-Mix Asphalt," Procedia Engineering, vol. 187, pp. 342-347, 2017.

[6] F. Y. An, H. Z. Ma, H. C. Wei and Z. P. Lai, "Distinguishing aeolian signature from lacustrine sediments of the Qaidam Basin in northeastern Qinghai-Tibetan Plateau and its palaeoclimatic implications," Aeolian Research, vol. 4, pp. 17-30. June 2012.

[7] E. Kalińska and M. Nartišs, "Pleistocene and Holocene aeolian sediments of different location and geological history: A new insight from rounding and frosting of quartz grains,"Quaternary International, vol. 328-329, pp. 311-322, April 2014.

[8] S. Vainer, Y. Erel and A. Matmon, "Provenance and depositional environments of Quaternary sediments in the southern Kalahari Basin,"Chemical Geology, vol. 476, pp. 352-369, Jan. 2018.

[9] W-L. Huang, X. P. Yang, A. Li, J. A. Thompson and L. Zhang, "Climatically controlled formation of river terraces in a tectonically active region along the southern piedmont of the Tian Shan, NW China," Geomorphology, vol. 220, pp. 15-29, Sept. 2014.

[10] D. Evans and D. Benn, 2004. A Practical Guide to the Study of Glacial Sediments. London: Routledge, 2004, 280 pp.

[11] M. Konert and J.Vandenberghe, "Comparison of laser grain size analysis with pipette and sieve analysis: a solution for the underestimation of the clay fraction," Sedimentology, vol. 44, pp. 523-535, 1997.

[12] R.M. Jones, "Particle size analysis by laser diffraction: ISO 13320 , standard operating procedures, and Mie theory,". American Laboratory, vol. 35, pp. 44-47, Jan. 2003

[13] R.L. Folk and W.C. Ward, "Brazos River bar, a study in the significance of grain-size parameters," Journal of Sedimentary Petrology, vol. 41(1), pp. 489-496, 1957.

[14] S.J. Blott and K. Pye, "GRADISTAT: a grain size distribution and statistics package for the analysis of unconsolidated sediments," Earth Surface Processes and Landforms, vol. 26, pp. 1237-1248, Sept. 2001.

[15] Z. Jiang and L. Liu, "A pretreatment method for grain size analysis of red mudstones," Journal of Sedimentary Geology, vol. 241, pp. 13-21, Nov. 2011.

[16] W.C. Mahaney, Atlas of Sand Grain Surface Textures and Applications, New York: Oxford University Press, 2002, 237 pp.

[17] K. Vos, N. Vandenberghe and J. Elsen, "Surface textural analysis of quartz grains by scanning electronmicroscopy (SEM): From sample preparation to environmental interpretation," Earth-Science Reviews, vol. 128, pp. 93-104, Jan. 2014.

[18] X. Zhang, Z. Li, P. Li, S. Cheng, Y. Zhang, S. Tang and T. Wang, "A model to study the grain size components of the sediment deposited in aeolian-fluvial interplay erosion watershed," Sedimentary Geology, vol. 330, pp. 132-140. Dec. 2015

[19] I. Livingstone, J.E.Bullard, G.F.S.Wiggs and D.S.G.Thomas, "Grain-size variation on dunes in the southwest Kalahari, Southern Africa," Journal of Sedimentary Research, vol. 69 (3), pp. 546-552, 1999.

[20] D.H. Krinsley and J. Donahue, "Environmental interpretation of sand grain surface textures by electron microscopy," Geological Society of America Bulletin, vol. 79, pp. 743-748, Jan. 1968.

[21] M. Kř́žek, K. Krbcová, P. Mida and M. Hanáček, "Micromorphological changes as an indicator of the transition from glacial to glaciofluvial quartz grains: Evidence from Svalbard," Sedimentary Geology, vol. 358, pp. 35-43, Aug. 2017.

[22] W.C. Mahaney and V. Kalm, "Comparative scanning electron microscopy study of oriented till blocks, glacial grains and Devonian sands in Estonia and Latvia,"Boreas, vol. 29 (1), pp. 35-51, June 2000. 